\title{
DIPLOMACY PROMOTION AND ECONOMIC DEVELOPMENT IN RWANDA A CASE OF UNITED STATES EMBASSY KIGALI
}

\author{
Mrs. Diana UWERA ${ }^{1 *}$, Dr. Paul MUNENE ${ }^{2}$ \\ ${ }^{*}$ School of Social Sciences, International Relations and Diplomacy, Mount Kenya University, Kigali, Rwanda, \\ ${ }^{2}$ Senior Lecturer, Mount Kenya University, Kigali, Rwanda \\ *lEmail: rhonic89@gmail.com, ${ }^{2}$ Email: munenepaul1@gmail.com
}

*Corresponding Author: -

Email: rhonic89@gmail.com

\begin{abstract}
: -
The Diplomacy performs a key role in shaping what takes area in international relations including bilateral relations, development aids, foreign policy and political and state interests. Diplomacy promotion is changing along with at least three dimensions, so the first is that in today's world household participants work nationally to meet famous challenges. Not long ago, diplomacy used to promote hobbies throughout the country, while development used to be once the eradication of poverty. The intentions of the researcher to conduct a study to find out the role of diplomacy promotion on economic development of Rwanda with specific consideration of the United States of America Embassy in Kigali. The researcher also used descriptive research design and while collecting data interview guide and questionnaire were used as data collection instrument. The study sampled 152 respondents from 246 employees of United Nations of America Embassy in Kigali. The data was analyzed using both descriptive and inferential statistic. In descriptive statistics mean and standard deviation was used while in inferential statistic correlation and regression analysis through use of SPSS version 21. The study results revealed that capacity building, social welfare and Poverty reduction has role in economic development of Rwanda. The study revealed that that the overall model had $R$ coefficient .975 reveals that diplomacy promotion (capacity building, social welfare and Poverty reduction) had a positive relationship with economic development of Rwanda. The coefficient of determination indicated by Adjusted $R$ square of 950 also indicates that capacity building, social welfare and Poverty reduction explains $95.0 \%$ the role economic development of Rwanda .Thus, it implies that predictors of economic development of Rwanda such as Per capital income of and Gross domestic product had $95.0 \%$. The findings of this study proved that there is a relationship between capacity building and economic development of Rwanda $(p=.773$ and sig=.000), between social welfare and economic development of Rwanda $(p=.783$ and sig=.000). Thus, it implies that there is a relationship between diplomacy promotion (capacity building, social welfare and Poverty reduction) and economic development with specific consideration of US Embassy Kigali. The researcher would like to recommend to the US Embassy Kigali to enhance the foreign policy regarding promotion of capacity building among the people living in Rwanda to ensure economic development. The researcher would also like to recommend to the beneficiaries of US Embassy Kigali projects to make sure that the projects run for them reduce poverty and enhance the welfare of their households because the results showing that there is a positive significant between diplomacy and poverty reduction, and social welfare in Rwanda.
\end{abstract}

Keywords: - Diplomacy Promotion, Economic Development, United States Embassy Kigali

\section{(우 (\$) (1)}




\section{INTRODUCTION}

Research have shown that however much efforts made by bilateral diplomatic relations and economic partnership developed for economic developed the small economies of Less Developed countries continues to suffer on global market (Steiner, 2004). Most of the African countries depend on subsidiary economy with low agricultural productivity, chronic malnutrition, chronic diseases that all together keep Africa into the vicious cycle of poverty (Rana, 2007).

Rwanda as any other poor country is committed to become middle - income country by 2020 as enshrined in its plan of vision 2020. The country is known to having very rapid economic development whereby is income generation activities dropped from $60 \%$ to $40 \%$ in just 3 years between 2011 to 2014, there was increase of life expectancy from 45 to 68 years due to capacity building, the social welfare increase from 0.3 dollars per day to more than a dollar per day, the under-five maternal mortality reduced by two thirds and achieved an extraordinary 85\% decline in maternal mortality in 1990 to 2015 , the survey also reported that $93 \%$ of the children aged 12-23 months are fully vaccinated against major childhood diseases (World Bank, 2017).

Regardless of the progress made by Rwandan Government, private sector, civil society, local and international investors, local and international non-governmental organization, diplomatic missions and other stakeholders. Researchers in this field of diplomacy and development have only taken into consideration the contribution of diplomacy in promoting bilateral relations and security but they have given less attention the role of diplomacy on promoting economic development of the country. Hence, the need to investigate the role of diplomacy on promoting the Rwanda's economic development taking a case to be aware of from the US embassy Kigali.

\subsection{Objectives of the study 1.1.1 General} objective

The general objective is to investigate role of diplomacy promotion on economic development of Rwanda with case study of United States of America Embassy in Kigali.

\subsubsection{Specific objectives}

(i) To assess the role of capacity building diplomacy on economic development of Rwanda

(ii) To examine role of social welfare diplomacy on economic development of Rwanda

(iii) To determine role of Poverty reduction diplomacy on economic development of Rwanda.

\section{Review of Literature}

\subsection{Diplomacy promotion}

Many researches have stressed the relevance of diplomatic relations in promoting the economic development of countries. They argue that participants of the diplomatic relationships between states amplify the kind of one visit, the opening of desire missions, consulates and embassies are determinants of the fabulous size of bilateral relations related to economic development between countries (Yakop \& Bergeijk, 2011; Moons \& Bergeijk, 2016). In contrast, strained diplomatic relations between states can also impair economic development between them (Fuchs \& Klann, 2013).

By evaluating the impact on diplomatic representations of developed and developing countries, Yakop and van Bergeijk (2011) grant clarification due to the fact diplomatic representations are even greater applicable to the creation of countries as they make contributions to the betterment of human beings of South-South diplomatic participants of the family . Moons and Bergeijk (2016) show that the effect of diplomatic substitutes is conditioned on the stage of development of shopping for and promoting partners of buying and selling companies for United States of America that the affection of diplomatic household humans is biggest in SouthSouth, North-South and South-North diplomatic relations in contrast to the NorthNorth diplomatic relations. The diplomatic relations between USA and African countries like Kenya, Ghana and South Africa is more productive than other North countries like European countries when it goes to trade relations and other economic development related relations.

The study of Moons and Bergeijk (2016) may be theoretically viable given that feasible market harm and coordination stemming from facts asymmetry can also additionally be in addition extra extreme for creating worldwide places compared to developed countries. However, his declaration on the importance of diplomatic representations for the South-South diplomatic members of the family has no longer been subjected to empirical verification in a gigantic contrast between countries for growing in Africa. The fundamental due to the fact that previous lookup that has analyzed the function of facilitating diplomatic relations of diplomatic exchange focuses completely on household contributors between northsouth, south-north and north-north partners.

For example, Afman and Maurel (2010) confined sampling to OECD international areas only, Head and Ries (2010), Canada export center of attention in financial diplomacy; it also limited the pattern to only cover exports as an element of diplomatic relations from advanced countries. Africa affords an interesting factor of view for the contrast of the two tools, as the region is referred to its severe stage of overlap and multi-participation in regional monetary integration schemes (Afesorgbor \& van Bergeijk, 2014). This assessment is specifically captivating as it is argued that regional integration limits the political lifestyles of member states of regional blocs and, due to this reality, leaves tons less room for bilateral negotiations (Woolcock, 2011 and van Bergeijk, 2011 ). Woolcock (2011) argues that prolonged regional integration would propose a good deal much less room for U.S. diplomacy through use of workable performance of member states.

\subsection{Economic Development}

In addition, most of these challenges are becoming more identified as currents, which potential that their consequences are worldwide hence the need for international cooperation to enhance diplomatic relations that foster the international 
agreements to address the need and interest of the home country. The global classes are divided into industrialized and developing nations that received a long way less assist in coping with the current international crisis.

Gerschenkron (2011) cited that the greater backward the United States is, the greater the role the United States desires to take in the advertising and marketing of its United States monetary improvement through reviewing the diplomatic ties to enhance partnership for economic development.

\subsection{Capacity Building diplomacy}

Ado et al., (2019) carried study on capacity Building in Africa: Toward an Imperative Mindset Transformation. The study used theories of mindset to explain some current development issues related to mindset in Africa but also to enlighten the reflection about the mindset transformation in Africa. The study draws the attention of international institutions for development and policymakers on the importance of mindset in the poor performance of capacity building programs in Africa and most importantly to explore strategies of mindset transformation in order to facilitate more effective capacity building programs and a sustainable development in African countries. The study points out some critical facts that reflect the imperative necessity of mindset transformation in Africa. The third part of the chapter will propose some strategies for mindset transformation in

Africa, Unfortunately, the results of such approach of development have been disappointing to some extent. While one should acknowledge that an economic transformation has been in progress in Africa.

Zimhunga et al., (2019) study on capacity building for Africa's transformation: a review of priorities and research needs. The study carried out various assessments, reports, studies, and surveys conducted by ACBF and other capacity development institutions show that while capacity to plan is advancing, there remains huge capacity challenges with regard to financing and implementation of development programs across countries. The study points out four priority research gap areas: how to affect a positive mind-set change, how to achieve economic diversification through resource-based industrialization, what works in domestic resource mobilization, and strategies for sustainable creation, utilization, retention and harmonization of skills including tapping on diaspora. The study found that $\mathrm{f}$ capacity building institutions such as the African Capacity Building Foundation (ACBF) and other stakeholders in coordinating the operationalization of the capacity building research agenda on the continent.

Ika and Donnelly (2019) studied under What Circumstances Does Capacity Building Work? The study looked into four capacity building projects in Ghana, Indonesia, Sri Lanka, and Vietnam, conduct a case study and a qualitative analysis of 20 interviews with project practitioners, and draw out their success conditions or the right circumstances under which they work. We find out that there are structural, institutional, and managerial conditions, some of which are initial (i.e., they occur in advance of the projects) and others are emergent (i.e., they occur in the wake of the projects). The study further identifies four meta-conditions for capacity building projects to succeed: multi-stakeholder commitment, collaboration, alignment, and adaptation. The study found that to obtain and maintain meta-conditions, proper attention should be given to attainability of objectives and demonstrating value, ability of stakeholders and inclusiveness, planning/design and mutual interest, and monitoring and support. Finally, submitted that capacity building projects thrive when there are high levels of multi-stakeholder commitment, collaboration, alignment, and adaptation.

\subsection{Social Welfare diplomacy}

Lewis \& Lloyd-Sherlock (2009) studied social policy and economic development in South America: an historical approach to social insurance in Brazil and the Argentine through the twentieth century. This study examines that welfare spending contributes to sustaining peace because the provision of social services reduces grievances by offsetting the effects of poverty and inequality in society. Welfare spending serves as an indication of the commitment of the government to social services and reflects its priorities and dedication to citizens.

By enacting welfare policies that improve the living standards of citizens, governments can co-opt the political opposition and decrease the incentives for organizing a rebellion. Utilizing time-series, cross-national data for the 1975-2005 period, the results indicate that as the level of the government investment in welfare policies (i.e. education, health, and social security) increases, the likelihood of civil conflict onset declines significantly, controlling for several other covariates of internal conflict. Additional data analysis shows that general public spending and military expenditures are unlikely to increase or decrease the probability of civil unrest. Overall, these findings suggest that certain types of public spending, such as welfare spending, might have a strong pacifying effect on civil conflict, and therefore the state's welfare efforts are vital for the maintenance of peace.

Magoma, (2019) studied the significant role of Tanzania's diplomacy towards economic development . The study has assessed and examined the significant contribution of Tanzania's diplomacy towards the economic development by describing and analyzing the evolution of Tanzania's foreign policy, major actors and players for the conduct of economic diplomacy and how the implementation of Tanzania's diplomacy has contributed to the economic prosperity by attracting of FDI, growth of trade activities, tourism sector and development of other economic sectors in the country through the rapid increase of external assistances. The study found that Implementation of sustainable economic diplomacy guided by the current foreign policy 2001 had brought impact to the social, political and economic development of Tanzania. The particular policy has increased the performance and participation of Tanzania in potential RECs and international organizations such as EAC, SADC, AU, UN and WTO where Tanzania acquired social and economic benefits including attraction of FDI, growth of trade activities, improvement of infrastructure, development of other economic sector, improvement of social services delivery which has helped in reducing the problem of poverty in the country and hence promoted the development of Tanzania's economy. 
Despite the recorded benefits resulting from the execution of the current foreign policy 2001, there are number challenges which affect or limit the effective implementation of the current foreign policy. Those challenges include shortage of funds, lack of adequate personnel (human capital), lack of coherent and consistent multiinstitutional framework for execution and poor link between the policy itself and other national development plans and strategies. The study recommend that the government should address these challenges by allocating enough financial resources, increase human capital and include other national development plans and strategies during the formation of new foreign policy. The concluded that with help increase the effective and meaningful participation of Tanzania in the execution of economic diplomacy for the betterment of the country with the view of achieving the rapid growth of Tanzania's economy

\subsection{Poverty Reduction diplomacy}

A successful strategy of poverty reduction must have at its core measures to promote rapid and sustained economic growth. The challenge for policy is to combine growth promoting policies with policies that allow the poor to participate fully in the opportunities unleashed and so contribute to that growth. This includes policies to make labour markets work better, remove gender inequalities and increase financial inclusion research that compares the experiences of a wide range of developing countries finds consistently strong evidence that rapid and sustained growth is the single most important way to reduce poverty. A typical estimate from these crosscountry studies is that a 10 per cent increase in a country's average income will reduce the poverty rate by between 20 and 30 per cent (Chen 2017).

Okoth (2012) maintained that economic diplomacy is the tactic used by the states to achieve their national interest, particularly economic interests, by cooperation with other states through well-informed negotiations and dialogue. Rana (2007) viewed economic diplomacy as how states deal with the rest of the world to secure their national gains and interests with regards to trade promotion, FDI attraction and other economic benefits through the agreed economic cooperation among the partner states. Mkhabela, 2013) focuses on how states make decisions within their countries, how they operate their external economic relations, and how they negotiate internationally. Mkhabela further, believes that economic diplomacy consists of a combination of all those processes.

\subsection{Foreign Policy diplomacy}

The researchers such as (Borcan, 2010; Murray et al., 2011 and Watson 2012) dealt foreign policy's economic areas and diplomatic relations asserted that there is a direct influence to the country's development strategy through exchange promotion; funding policy; and economic, financial, and organizational negotiations. While in the political sphere, the tensions of the motion are greater than roundly associated to the advertising of economic improvement, as sensible efforts that now do no longer acquire the financial and social areas so quickly, however, assist to create an incredible environment for one of a sort action stresses to be triumphant in phrases of beneficial rights of useful resource exploration, global cooperation, and international projection. Historical accounts for the contribution of diplomatic relation in improving the economic development of Less Developed countries as leadership role with the assist of prescribing liberal policies abroad, deploying interventionist practices for economic development. In the problem of worldwide relations, Arrighi (2010) considered the need for a sturdy us of a presence to bridge the gap between the core and the periphery and the semiperiphery, at the same time as offering a pessimistic view of actual possibilities for to the joint financial development of the backward international areas or nations.

According to Feder (2012), exports lead to an increased economic increase as a substitute than mere contribution to GDP. The wider involvement of the nation's leaders and the authorities in the implementation of the country's overseas policy, diplomatic members of the family and their specific interest to change has led many analysts to evaluate them in front of sellers, an alternative promotion of funding policy; and economic, monetary, and industrial negotiations. While in the political sphere, the lines of movement are greater intently related to the merchandising of financial improvement, as the realistic efforts that no longer attain the monetary and social areas so quickly, but help to create an surroundings valuable so that the distinct tensions of motion be triumphant in terms of the rights of aid exploration, worldwide cooperation and world projection. But, still they leave a room for economic development when they are played fairly in diplomatic relation with other political friends.

Foreign policy is an essential instrument in the international relations discipline and it is regarded as a blueprint that provides essential guidelines and frameworks for the implementation of diplomacy in any country. "The only aspect that distinguishes it from other policies is that foreign policy is implemented for the aim of achieving the national interests in relations to other states. According to (Modelski, 1962) foreign policy is a system of activities developed by the state to transform the action or behavior of other states as a way of modifying their self-concerns to the global environment. Modelski believes that, the primary role of foreign policy is to ensure the attainment of the national interest by changing the existing behaviors of other states. However, (Padelford, \& Lincoln, 1967) argues that foreign policy is an essential aspect in the situation where the state translates its desired targets and interests into action in order to attain these objectives and protect its national interests. Nevertheless, (Gibson, 1944) described foreign policy as an extensive strategy, plan or guideline which provides the information, experience and knowledge on how the government or state should administer its activities with the rest of the world for the aims of promoting, advocating, and protecting the interest of the particular state.

\section{Materials and Methods}

The descriptive research design was used to collect data with the help of qualitative and quantitative approaches from the primary respondents, US Embassy Kigali Annual reports and Magazines. Other sources include media publications such as newspapers were analyzed through descriptive methods and use for SPSS to generate correlation and multiple linear 
regression analysis. The research collected information using descriptive research design on diplomacy promotion and economic development were collected from 152 respondents selected form 246 employees of United States (US) Embassy in Kigali. Thus, the descriptive data were analyzed using mean and standard deviation; and the regression analysis and correlation to finding the rapport between diplomacy promotion and economic development. To collect data, the researcher used questionnaire to 138 respondents from management, regional security office and public diplomacy while interview guide were scheduled for 14 respondents from executive and consular sections to record all the information in relation to research objective

Data analysis process included data sorting, editing, coding, or variable generation, data entry, cleaning, processing using SPSS 21.0 version. In descriptive statistics, mean and standard deviation was used while in inferential statistic correlation and regression analysis correlation analysis Spearman correlation was used to establish the strengths of relationship while in regression multiple linear regression analysis was used to establish relationship between role diplomacy promotion (capacity building, social welfare and poverty reduction) and economic development in Rwanda. T-test and F test, a statistic was considered to be statistically significant when the value of the test statistic falls in the critical region and in this case, the null hypothesis was rejected and the alternative was upheld.

The general multiple regression models that was specified and tested in this study are given in equation in for equations as $\mathrm{Y} 1_{\text {it }}=\beta 0+\beta_{1} \mathrm{CB}_{\text {it }}+\beta_{2} \mathrm{SW}_{\text {it }}+\beta_{3} \mathrm{PR}_{\mathrm{it}}++\varepsilon$ and $Y 2_{i t}=\beta 0+\beta_{1} \mathrm{CB}_{\mathrm{it}}+\beta_{2} \mathrm{SW}_{\mathrm{it}}+\beta_{3} \mathrm{PR}_{\mathrm{it}}++\varepsilon$. Where: $\mathrm{Y} 1_{\text {it }}=$ economic development in Rwanda proxy by per capital income $\mathrm{i}$ at time $\mathrm{t}, \mathrm{Y} 2_{\mathrm{it}}=$ economic development in Rwanda proxy by GDP $i$ at time $t, \beta_{0}=$ Constant for each economic development in Rwanda (fixed effects), $(\beta \mathrm{i} ; \mathrm{i}=1,2,3$,$) ) Regression coefficients$ values, $(\mathrm{CBi}$; $\mathrm{SWi}$; PRi; $=1,2,3)=$ values of various independent variables, $\varepsilon_{\mathrm{it}}=$ composite error term(the residual error of the regression), $\mathrm{CB}_{\mathrm{it}}=$ Capacity Building diplomacy of US embassy $i$ at time $t . \mathrm{SW}_{\mathrm{it}}=$ Social welfare diplomacy of US embassy $i$ at time $t$. $\mathrm{PR}_{\mathrm{t}}=$ Poverty reduction diplomacy of US embassy $i$ at time $t$. $\mathrm{t}=2015$ to 2019 .

\section{Research Findings}

\subsection{Role of capacity building diplomacy on economic development in Rwanda}

Table 4. 1: Statements regarding role by capacity building of diplomacy on economic development in Rwanda

\begin{tabular}{|c|c|c|c|c|c|c|}
\hline Role by capacity building of diplomacy & 5 & 4 & 3 & 2 & 1 & Mean Std. \\
\hline \multicolumn{7}{|l|}{ Capacity building Diplomacy affect nutritional } \\
\hline condition & $0.7 \%$ & $2.6 \%$ & $6 \%$ & $14(9.2 \%)$ & \multirow{2}{*}{\multicolumn{2}{|c|}{$\begin{array}{lr}129(84.9 \%) & 1.2500 .69292 \\
83.6 \% & 1.2566 .67595\end{array}$}} \\
\hline apacity building Diplomacy improves lifestyles & & & & & & \\
\hline \multicolumn{7}{|l|}{ Capacity building Diplomacy brings about better } \\
\hline $\begin{array}{l}\text { Capacity building Diplomacy enhances qual } \\
\text { health services }\end{array}$ & $0.7 \%$ & $2.0 \%$ & $3.3 \%$ & & & 1.2566 .67595 \\
\hline $\begin{array}{l}\text { Capacity building Diplomacy improves infa } \\
\text { mortality conditions }\end{array}$ & $0.7 \%$ & $2.6 \%$ & $2.6 \%$ & $7.2 \%$ & $86.8 \%$ & 1.2303 .68542 \\
\hline $\begin{array}{l}\text { Capacity building Diplomacy improves premat } \\
\text { nortality conditions }\end{array}$ & $0.7 \%$ & $2.0 \%$ & $3.3 \%$ & & $83.6 \%$ & 1.2566 .67595 \\
\hline $\begin{array}{l}\text { Capacity building Diplomacy affect median age } \\
\text { population }\end{array}$ & $0.7 \%$ & $2.6 \%$ & $2.6 \%$ & $16.4 \%$ & $77.6 \%$ & 1.3224 .71504 \\
\hline $\begin{array}{l}\text { Diplomacy affect disability free and healthy } \\
\text { expectancy } \\
\text { Total Mean }\end{array}$ & 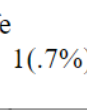 & 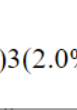 & & & & 1.2441 \\
\hline
\end{tabular}

Source: Primary Data, 2021

The results in Table 4.1 is represented in The Likert Scale data are presented in scale of 1 to 5 where 1 - strongly agree, 2 - agree, 3-neutral, 4- disagree, 5- Strongly Agree. Thus, the findings demonstrate $84.9 \%$ of respondents strongly agreed that capacity building Diplomacy affect nutritional condition with mean of 1.2500. and standard deviation of $69292.83 .6 \%$ respondents strongly agreed that capacity building Diplomacy improves lifestyle, mean of 1.2566. and standard deviation of $0.67595 .86 .8 \%$ of respondents strongly agreed that capacity building diplomacy brings about better education mean of 1.2303 and standard deviation of $0.68542 .83 .6 \%$ of respondents strongly agreed that capacity building diplomacy enhances quality health services, $86.8 \%$ of respondents strongly agreed that capacity building diplomacy improves infant mortality conditions, $83.6 \%$ of respondents strongly agreed that capacity building diplomacy improves premature mortality conditions, $77.6 \%$ of respondents strongly agreed that capacity building diplomacy affect median age of population, $83.6 \%$ of respondents strongly agreed that capacity building diplomacy affect disability free and healthy life expectancy. The results also have indicated that mean from 1.1382 to 1.2566 implying that diplomacy has a significant positive contribution to capacity building of people living in Rwanda. The total mean of 1.2441 which tends to the highest score of 1 supports that capacity building diplomacy contributes to economic development of people living in Rwanda.

In an interview conducted on 26 August 2020 with one of the executives of US Embassy in Kigali, has stipulated that they have donated a lot of money for capacity building, training and sponsored further educations under their programs of capacity building. Hence, this proves that diplomacy contributes to capacity building of the people living in Rwanda.

The findings of the current study are supported by the study of Murray et al., (2011) who dealt with the economic area of foreign policy and diplomatic relations and asserted that there is a direct influence to the national development strategies that are attainable through promotion of trade, investment policy and economic that are done for the sake of capacity building among countries. 
Table 4.2. Model Summary of capability building diplomacy and economic development

\begin{tabular}{lllll}
\hline Model & $\mathrm{R}$ & R Square & Adjusted R Square & Std. Error of the Estimate \\
& $.975^{\mathrm{a}}$ & .950 & .949 & .11366 \\
\hline
\end{tabular}

a. Predictors: (Constant), capacity building diplomacy

Source: Primary Data, 2021

The results of Table 4.2 demonstrated that the R .975 coefficient showing that capacity building diplomacy has relationship with economic development. The $.950 \mathrm{R}$ squared coefficient shows that diplomacy explains 95 percent of the variability in capacity building. It consequently implies that predictors of capacity building diplomacy play role on economic development progress by $95.0 \%$ in Rwanda people with help of US Embassy Kigali.

Table 4. 3: Analysis of Variance (ANOVA) of capacity building diplomacy

\begin{tabular}{llllll}
\hline Model & Sum of Squares & Df & Mean Square & F & Sig. \\
\hline Regression & 36.187 & 3 & 12.062 & 933.748 & $.000^{2}$ \\
Residual & 1.912 & 148 & .013 & & \\
Total & 38.099 & 151 & & & \\
\hline
\end{tabular}

a. Dependent Variable: Capacity Building

b. Predictors: (Constant), economic development

Source: Primary Data, 2021

The results of the study in Table 4.3 have revealed the significant relationship between capacity building diplomacy and economic development as indicated by the calculate significance value of 0.00 which is lesser than 0.05 level of significance. Thus, the results from the model have shown relationship between capacity building diplomacy and economic development is significant.

Table 4. 4: Coefficients of capacity building diplomacy and economic development

\begin{tabular}{|c|c|c|c|c|c|}
\hline \multirow[t]{2}{*}{ Model } & \multicolumn{2}{|c|}{ Unatandardized Coefficients } & \multirow{2}{*}{$\begin{array}{l}\text { Standardized Coefficients } \\
\text { Beta }\end{array}$} & \multirow[t]{2}{*}{$\mathrm{T}$} & \multirow[t]{2}{*}{ Sig. } \\
\hline & B & Std. Error & & & \\
\hline (Constant) & .024 & .023 & & 1.062 & .290 \\
\hline Capacity Building & 3.649 & .176 & 4.018 & 20.686 & .000 \\
\hline
\end{tabular}

a. Dependent Variable: Capacity Building

Source: Primary

Data, 2021

The results in Table 4.4 have revealed the positive coefficients of Capacity Building diplomacy that promote the positive progress of economic development in Rwanda with the help of US Embassy Kigali. The multiple regression results have proven that all calculated p-values are lesser than 0.05 which showed the positive and significant relationship between capacity building diplomacy and economic development as by the simple regression model of $\mathrm{Y}=\beta 0+\beta 1 \mathrm{x} 1+\alpha$. This multiple regression model becomes $=.0 .24+0.3 .649$ Capacity Building diplomacy $+\alpha$. Since, the model means when capacity building diplomacy is held constant economic development will be 0.24 while unit of capacity building diplomacy will lead to 0.3.649 economic development .The first hypothesis that $\mathrm{H} 01$ there is no significant relationship between capacity building diplomacy and economic development $\mathrm{P}=.000$ is less than 0.005 hence we fail to reject hypothesis and conclude that there is no significant relationship between capacity building diplomacy and economic development in Rwanda by help of US Embassy Kigali.

\subsection{Social Welfare and Economic Development}

This section of the study covers the perceptions and views of respondents in relation to the role played by social welfare diplomacy on economic development of people living in Rwanda that is measured from the statements regarding social welfare diplomacy on economic development of people living in Rwanda. The Likert Scale data are presented in a scale point of 1 to 5 where 1 - strongly agree, 2 - agree, 3 - neutral, 4 - disagree, 5- strongly agree which rates agreement on role played by social welfare diplomacy on economic development of people living in Rwanda. 
Table 4. 5: Statements regarding the role social welfare of people on Economic development in Rwanda Role played by social welfare diplomacy on economic development

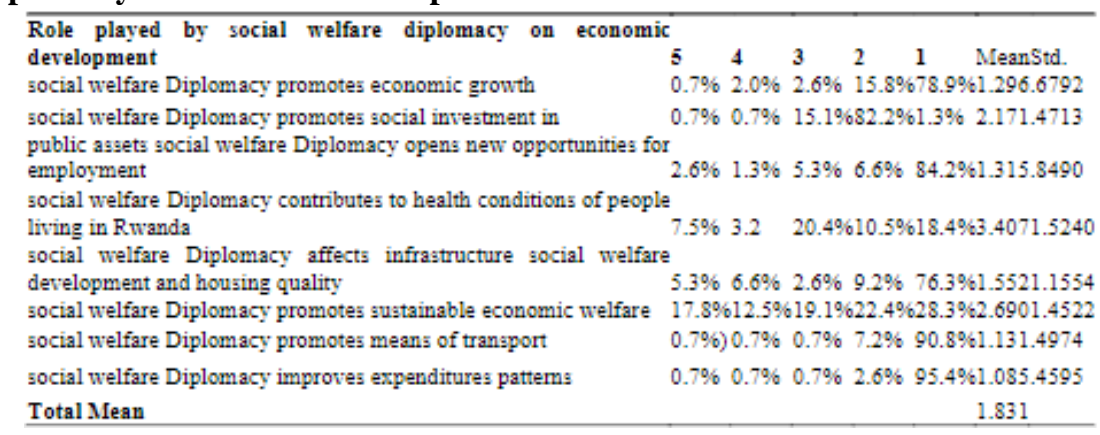

Source: Primary Data, 2021

The results in Table 4.5 show $78.9 \%$ of respondents strongly agreed that social welfare Diplomacy promotes economic growth, $82.2 \%$ of respondents agreed that economic development attained through social welfare diplomacy promotes social investments in public assets, $90.8 \%$ of respondents strongly agreed that economic development attained through social welfare diplomacy promotes means of transport, $95.4 \%$ of respondents strongly agreed that social welfare economic development attained through social welfare diplomacy promotes expenditure patterns, $84.2 \%$ of respondents strongly agreed that economic development attained through social welfare diplomacy opens new opportunities for employment, $76.3 \%$ of respondents strongly agreed that economic development attained through social welfare diplomacy affects infrastructure development and housing quality, 37.5\% of respondents strongly disagreed that economic development attained through social welfare diplomacy contributes to health conditions, $28.3 \%$ of respondents strongly agreed that economic development attained through social welfare diplomacy promotes economic development sustainable. The results also show that mean ranges from 1.0855 to 2.6908 despite the mean of views regarding economic development attained through social welfare diplomacy contributes to health conditions of people living in Rwanda which is 3.4079 meaning that social welfare diplomacy promotes the economic development of people living in Rwanda. The total mean of 1.8314 which tends to the highest score supports that social welfare diplomacy promotes economic development of the people living in Rwanda.

In an interview conducted on 26 August 2020 with one of the Executive of US Embassy has said that the US Embassy has donated a lot of money to contribute and support social welfare of the people living in Rwanda. This means that social welfare was promoted by the diplomacy applied through US Embassy among the people living in Rwanda.

The results of this research are supported by means of the findings of the getting to know of Watson (2012), who performed a know-how on the financial location of overseas coverage and diplomatic relations have posted that coverage areas exhibit the lines of motion more associated to By promotion economic development, practical efforts now fail to reach the financial and social areas to create a super environment for the different traces of actions to be success when it goes to international cooperation, resource exploration and international projection which also help to attain social welfare among the people.

Table 4. 6: Model Summary of social welfare diplomacy and economic development

\begin{tabular}{clll}
\hline ModelR & R Square & Adjusted R Square & Std. Error of the Estimate \\
$.938^{2}$ & .880 & .877 & .18200 \\
\hline
\end{tabular}

a. Predictors: (Constant), social welfare diplomacy

Source: Primary Data, 2021

The results in Table 4.6 confirmed the relationship between social welfare diplomacy and economic development because the $\mathrm{R}$ coefficient is .938 and the coefficient of determination as the .877 Adjusted R square also suggests that diplomacy enhances $87.7 \%$ of the variability of social welfare diplomacy. It consequently implies that predictors of social welfare diplomacy can explain economic development by $87.7 \%$ in Rwanda by US Embassy Kigali. ‘

Table 4. 7: Analysis of Variance (ANOVA) of diplomacy and social welfare

\begin{tabular}{llllll}
\hline Model & Sum of Squares & Df. & Mean Square & F & Sig. \\
Regression & 35.913 & 3 & 11.971 & 361.397 & $.000^{5}$ \\
Residual & 4.902 & 148 & .033 & & \\
Total & 40.816 & 151 & & & \\
\hline
\end{tabular}

a. Dependent Variable: Social Welfare

b. Predictors: (Constant), economic development

Source: Primary Data, 2021

The results in Table 4.7 indicated calculated significance value of .000 which is lesser that 0.05 that proves the significant relationship between social welfare diplomacy and economic development. Thus, the statistical significance of the study shows the relationship between social welfare diplomacy and economic development as positive and significant. 
Table 4. 8: Coefficients of social welfare diplomacy and economic development

\begin{tabular}{llllll}
\hline Model & \multicolumn{2}{l}{ Unstandardized Coefficients } & Standardized Coefficients & T & Sig. \\
& $\mathrm{B}$ & Std. Error & Beta & & \\
(Constant) & .035 & .037 & & .961 & .338 \\
Social Welfare diplomacy & .062 & .047 & .068 & 1.310 & .009 \\
\hline
\end{tabular}

a.

Dependent Variable: economic development Source: Primary Data, 2021

The findings in Table 4.8 proved the positive effect of social welfare diplomacy to economic development in Rwanda by the help of US Embassy Kigali because the calculated coefficients are positive and significant. The simple regression analysis also confirms the positive and significant relationship also due to the fact that all calculated $\mathrm{p}$ values are greater than 0.05 and the multiple regression model, $Y=\beta 0+\beta 2 \times 2+\beta 3 \times 3+\alpha$ which turns into multiple regression model with $\mathrm{Y}=.035+0.062$ social welfare diplomacy $+\alpha$. Thus, when social welfare diplomacy is held constant economic development in Rwanda brought by US Embassy Kigali will be 0.035 . Unit of social welfare diplomacy will lead to 0.062 economic development in Rwanda brought by US Embassy Kigali

The second hypothesis $\mathrm{H} 02$ there is no significant relationship between economic factor of social welfare diplomacy and economic development $\mathrm{P}=.009$ is greater than 0.005 hence we reject null hypothesis and conclude that there significant relationship between economic factor of social welfare diplomacy and economic development in US Embassy Kigali.

\subsection{The Role played by poverty reduction diplomacy on economic development in Rwanda}

This section of the study presents and discusses the views and perceptions of respondents in regard to role played by Poverty reduction on economic development through diplomacy reduces poverty gap ratio up to economic development achieved through diplomacy reduces vulnerability and violence of human rights. The Likert Scale data are presented in scale of 1 to 5 point where 1 - strongly agree, 2 -agree, 3 - neutral, 4 - Disagree, and 5 - strongly disagree which rates the agreement on role played by Poverty reduction on economic development.

Table 4. 9: Statements regarding role played by Poverty reduction diplomacy on economic development in Rwanda

\begin{tabular}{|c|c|c|}
\hline Role played by Poverty reduction diplomacy & 5 & Mean Std. \\
\hline Poverty reduction Diplomacy reduces poverty gap ratio & $6.6 \%) 8.6 \% 3.8 \% 11.2 \%$ & $9.9 \% 1.90791 .29367$ \\
\hline Poverty reduction Diplomacy reduces inequality & $0.7 \% 0.7 \% 0.7 \% 6.6 \%$ & $91.4 \% 1.1250 .49249$ \\
\hline Poverty reduction Diplomacy reduces child malnutrition & $0.7 \% 2.6 \% 2.6 \% 3.3 \%$ & $90.8 \% 1.1908 .66843$ \\
\hline Poverty reduction Diplomacy reduces adult illiteracy rate & $0.7 \% 6.6 \% 6.6 \% 7.9 \%$ & $8.3 \% \quad 1.4342 .92551$ \\
\hline Poverty reduction Diplomacy reduces infant rate & $0.7 \% 0.7 \% 0.7 \% 7.2 \%$ & $90.8 \% 1.1316 .49747$ \\
\hline Poverty reduction Diplomacy reduces maternal mortality rat & $\% 5.3 \% 5.9 \%$ & $8.9 \% \quad 1.48681 .05471$ \\
\hline $\begin{array}{l}\text { Poverty reduction Diplomacy reduces depth and severity } \\
\text { Poverty reduction Diplomacy reduces vulnerability and } \\
\text { violence of human rights }\end{array}$ & $\begin{array}{l}7.2 \% 10.52 .6 \% 3.3 \% \\
0.7 \% \quad 8.6 \% 9.2 \% 13.2 \%)\end{array}$ & $\begin{array}{r}76.3 \% 1.69081 .33339 \\
) 68.4 \% 1.59871 .01159\end{array}$ \\
\hline Total Mean & & 1.4457 \\
\hline
\end{tabular}

Source: Primary Data, 2021

The results in Table 4.9 indicate $91.4 \%$ of respondents strongly agreed that economic development achieved through Poverty reduction diplomacy reduces inequality, $90.8 \%$ of respondents strongly agreed that economic development achieved through diplomacy reduces child malnutrition, $90.8 \%$ of respondents strongly agreed that economic development achieved through diplomacy reduces infant rate, $78.9 \%$ of respondents strongly agreed that economic development achieved through diplomacy reduces maternal mortality rate, $76.3 \%$ of respondents strongly agreed that economic development achieved through Poverty reduction diplomacy reduces depth and severity, $78.3 \%$ of respondents strongly agreed that economic development achieved through Poverty reduction diplomacy reduces adult illiteracy rate, $68.4 \%$ of respondents strongly agreed that economic development achieved through diplomacy reduces vulnerability and violence of human rights $59.9 \%$ of respondents strongly agreed that economic development achieved through diplomacy reduces poverty gap ratio. The results show that mean ranges from 1.1250 to 1.9079 which implies that the economic development has a positive significant effect on poverty reduction among people living in Rwanda. The total mean of 1.4457 which tends to the highest score which is 1 supports the results implying that economic development reduces poverty among the people living in Rwanda.

In another interview conducted on 29 August 2020 with another executive of US Embassy in Kigali he asserted that US Embassy has started a number of programs under the Embassy and its organs like USAID that contribute to poverty reduction among the people living in Rwanda. The programs of US Embassy also contributes to fight against malnutrition together with a number of Hospitals. Hence, this implies that US Embassy diplomacy contributes in poverty reduction among the people living in Rwanda. The results of this study have shown a positive and significant relationship between poverty reduction diplomacy and is supported by the study of Wang (2006) who asserted that during the end of second millennium, development and diplomacy started to join up together in the field of peace, human rights and security, international trade, sustainability of environment, change of local weather, global health, development of private sector, right to drinking water, absence of poverty and right to food.

Table 4. 10: Model Summary of poverty reduction diplomacy and economic development

\begin{tabular}{llll}
\hline Model & R $\quad$ R Square & Adjusted R Square & Std. Error of the Estimate \\
& $.927^{2} .858$ & .856 & .19930 \\
\hline
\end{tabular}

a. Predictors: (Constant), economic development.

Source: Primary Data, 2021 
The results of Table 4.10 demonstrate that the $\mathrm{R} .927$ coefficient suggests that poverty reduction diplomacy has a relationship with economic development. The coefficient of dedication .856 adjusted $\mathrm{R}$ square also indicates that poverty reduction diplomacy explains $85.6 \%$ the variability of economic development. It further implies that predictors of poverty reduction diplomacy like political factors of diplomacy, economic factors of diplomacy and social factors of diplomacy explain $85.8 \%$ economic development in Rwanda by help of US Embassy Kigali therefore there are other factors that explains $14.2 \%$ economic development in Rwanda by help of US Embassy Kigali.

Table 4. 11: Analysis of Variance (ANOVA) of poverty reduction diplomacy (ANOVA)

\begin{tabular}{llllll}
\hline Model & Sum of Squares & Df. & Mean Square & F & Sig. \\
\hline Regression & 35.641 & 3 & 11.880 & 299.106 & $.000^{\mathrm{b}}$ \\
Residual & 5.879 & 148 & .040 & & \\
Total & 41.520 & 151 & & & \\
\hline
\end{tabular}

a. Dependent Variable: Poverty reduction

b. Predictors: (Constant), economic development.

Primary Data, 2021

The results in Table 4.11 indicated the calculated significance value of .000 which is lesser than .05 level of significance that proves the significant and positive relationship between poverty reduction diplomacy and economic development.in Rwanda.

Table 4. 12: Coefficients of poverty reduction diplomacy

\begin{tabular}{llllll}
\hline Model & \multicolumn{2}{l}{ Unstandardized Coefficients } & Standardized Coefficients & T & Sig. \\
& $\mathrm{B}$ & Std. Error & Beta & & \\
(Constant) & .046 & .040 & & 1.150 & .252 \\
poverty reduction diplomacy & .059 & .052 & .065 & 1.145 & .004 \\
\hline
\end{tabular}

a. Dependent Variable: economic development.

Source: Primary Data, 2021

The results of Table 4.11 indicate the calculated significance level which are less than 0.05 which implies that poverty reduction diplomacy plays role in has a economic development by help of US Embassy Kigali. The multiple regression analysis as presented by $\mathrm{Y}=\beta 0+\beta 3 \times 3+\alpha$ have become $\mathrm{Y}=.046+059$ poverty reduction diplomacy. Thus, when poverty reduction diplomacy is held constant economic development in Rwanda brought by US Embassy Kigali will be 0.046. Unit of poverty reduction diplomacy will lead to 0.059 economic development in Rwanda brought by US Embassy Kigali. The third hypothesis $\mathrm{H} 03$ there is no significant relationship between poverty reduction diplomacy and economic development because ( $\mathrm{p}=.004)$ is less than 0.005 hence we fail to reject null hypothesis and conclude that significant relationship between poverty reduction diplomacy and economic development brought by US Embassy Kigali.

Table 4. 12: Correlation analysis between role diplomacy promotion (Poverty reduction, Social Welfare and Capacity Building) and economic development

\begin{tabular}{|c|c|c|c|c|c|}
\hline & & $\begin{array}{l}\text { Economic } \\
\text { development }\end{array}$ & $\begin{array}{l}\text { Poverty } \\
\text { reduction }\end{array}$ & $\begin{array}{l}\text { Social } \\
\text { Welfare }\end{array}$ & $\begin{array}{l}\text { Capacity } \\
\text { Building }\end{array}$ \\
\hline Economic & Pearson & .000 & & & \\
\hline \multirow[t]{3}{*}{ development } & Correlation & & $.773 * *$ & $.783^{* *}$ & $.814 * *$ \\
\hline & Sig. (2-tailed) & .000 & .000 & .000 & .000 \\
\hline & $\mathrm{N}$ & 152 & 152 & 152 & 152 \\
\hline \multirow[t]{4}{*}{ Poverty reduction } & Pearson & & & & \\
\hline & Correlation & $.773^{* *}$ & .000 & $.783 * *$ & $.814 * *$ \\
\hline & Sig. (2-tailed) & .000 & .000 & .000 & .000 \\
\hline & $\mathrm{N}$ & 152 & 152 & 152 & 152 \\
\hline \multirow[t]{4}{*}{ Social Welfare } & Pearson & & & & \\
\hline & Correlation & $.783^{* *}$ & $.841 * *$ & .000 & $.874 * *$ \\
\hline & Sig. (2-tailed) & .000 & .000 & .000 & .000 \\
\hline & $\mathrm{N}$ & 152 & 152 & 152 & 152 \\
\hline \multirow[t]{4}{*}{ Capacity Building } & Pearson & & & & \\
\hline & Correlation & $.814^{* *}$ & $.806 * *$ & $.838 * *$ & .000 \\
\hline & Sig. (2-tailed) & .000 & .000 & .000 & .000 \\
\hline & $\mathrm{N}$ & 152 & 152 & 152 & 152 \\
\hline
\end{tabular}

The findings in Table 4.11 prove that there is a relationship between Economic development and poverty reduction diplomacy $(\mathrm{p}=.773$ and $\mathrm{sig}=.000)$, between Economic development and social welfare diplomacy $(\mathrm{p}=.783 \mathrm{and} \mathrm{sig}=.000)$, between economic factor of diplomacy and capacity building ( $\mathrm{p}=.814$ and sig=.000), between social factor of diplomacy and poverty reduction $(\mathrm{p}=.830$ and $\mathrm{sig}=.000)$, between poverty reduction diplomacy and social welfare $\operatorname{diplomacy}(\mathrm{p}=.841$ 
and sig=.000), between Economic development and capacity building diplomacy ( $\mathrm{p}=.874$ and sig=.000), between capacity building and poverty reduction ( $\mathrm{p}=.806$ and $\mathrm{sig}=.000)$, between Poverty reduction diplomacy and social welfare $(\mathrm{p}=.783$ and sig=.000), between social welfare diplomacy and capacity building $(\mathrm{p}=.838$ and $\operatorname{sig}=.000)$. It therefore implies that there is significant relationship between diplomacy and economic development with a support of the US embassy Kigali. The effects of the present day learn about suggest that there is a significant relationship between diplomacy and monetary development. Hence, it is supported by the study of Gerschenkron (2011) which stated that the more backward a country is; the greater the role the state needs to play in promoting its economic development through reviewing the diplomatic ties to enhance partnership for economic development. It is also supported by the study of Amsden (2001) and Chang (2002) that states that diplomatic relation contributes in improving the economic development of Less Developed countries as leading position by prescribing liberal policies abroad while deploying interventionist practices for economic development.

\subsection{Conclusion}

In conclusion, therefore, for the objective one, the results of the study indicated that capacity building diplomacy plays important role in economic development of Rwanda were at suitable level as indicated by the findings though there is a room for improvement as multiple regression results have proven that all when capacity building diplomacy has no significant relationship between capacity building diplomacy and economic development $\mathrm{P}=.000$ is less than $0.005 \mathrm{t}$ in Rwanda by help of US Embassy Kigali.

For objective two, social welfare diplomacy plays important role in on economic development of Rwanda as indicated by the findings though .877 Adjusted R square also suggests that diplomacy enhances $87.7 \%$ of the variability of social welfare diplomacy and total mean of 1.8314 which tends to the highest score supports that diplomacy promotes social welfare of the people living in Rwanda The regression result further showed that a significant relationship between social welfare diplomacy and economic development $\mathrm{P}=.009$ in US Embassy Kigali.

Lastly, for objective three, based on the study findings, the researcher concluded that Poverty reduction diplomacy on economic development of Rwanda as justified by inferential statistics results in Table 4.11 indicated the calculated significance value of .000 which is lesser than .05 level of significance that proves the significant and positive relationship between poverty reduction diplomacy and economic development.in Rwanda though there is a room for improvement there was no significant relationship between poverty reduction diplomacy and economic development because $(\mathrm{p}=.004)$ is less than 0.005 hence we fail to reject null hypothesis and conclude that significant relationship between poverty reduction diplomacy and economic development brought by US Embassy Kigali. The research has revealed that the diplomatic relations has direct influence to the country's development strategy through enhancing promotion of trade, policy of investment and both commercial and economic negotiation.

\subsection{Acknowledgement}

Firstly, Above all, I owe great appreciations to the Almighty God who gave me a life and strength to accomplish my master's degree program. My thanks go to the Mount Kenya University which equipped me with knowledge and skills necessary for a successful future. Special thanks also go to my Supervisor Dr. Paul Munene, my Lecturers Mr. Oscar Kimanuka and Mr. Anyama Charles, for guidance, recommendation, and time during the writing process of this research project. This research project would not have possible with support of United states (US) Embassy Kigali for allowing me to collect data for this research project. This research project would not have been carried out in any way without the encouragement and devotion of my family especially my husband and auntie Beatrice. I also owe thanks to my brothers and sisters who encouraged while compiling this research project and I cannot forget the contribution of my classmates and friends. I would like to thank everyone not mentioned here for his or her contribution to the success of my study. Thank you all very much!.

\section{References}

[1].Borcan, K., (2010). Diplomacy and Cosmopolitanism in a Globalized World. Journal of International and Global Studies.

[2].Ika, L., \& Donnelly, J. (2019). Under What Circumstances Does Capacity Building Work?. In Capacity Building in Developing and Emerging Countries (pp. 43-90). Springer, Cham.

[3].Lewis, C. M., \& Lloyd-Sherlock, P. (2009). Social policy and economic development in South America: an historical approach to social insurance. Economy and Society, 38(1), 109-131.

[4].Magoma, S. M. (2019). The Significant role of Tanzania's diplomacy towards economic development Upblushed master of public management thesis, KDI School.

[5].Munthali, T., Diawara, B., \& Zimhunga, A. (2019). Capacity Building for Africa's Transformation: A Review of Priorities and Research Needs. Capacity Building in Developing and Emerging Countries, 91-118.

[6].Murray, S. M., Sharp, P., Wiseman, G., Criekemans, D. \& Melissen, J. (2011). The Present and Future of Diplomacy and Diplomatic Studies. International Studies Review.

[7].Ramona, O. G., (2017). Economic Diplomacy and Its Impact on Economic Development, Management Intercultural Romanian Foundation for Business Intelligence, Editorial Department, issue 39. 